\title{
Neuropsychological Deficits, Depression and Type a Behavior Pattern in Patients with Myocardial Infarction
}

\author{
Sherin P. Antony and M. I. Joseph
}

\begin{abstract}
In cardiovascular disease, which is one of the leading causes of death in developing countries, the majority of deaths are due to myocardial infarction (MI). Myocardial infarction occurs when the blood supply to parts of the heart is interrupted causing some heart cells to die. Myocardial infarction may lead to cognitive deficits. The main causes or risk factors of myocardial infarction are hypertension, diabetes mellitus and tobacco use. Psychosocial factors such as Type A behavior pattern or coronary prone behavior and depression have been reported to be associated with myocardial infarction. The aim of the present study was to examine the presence of depression and neuropsychological deficits in patients with myocardial infarction. In addition, Type A behavior pattern or coronary prone behavior of patients with MI was also examined. The sample consisted of 40 MI patients and the tests were administered within one week after hospitalization. A healthy normal comparison group of 40 subjects, who were matched with respect to age, education, gender, place and state of residence with the MI patient group, was also selected for the study. The tools used were Beck depression inventory, Edinburgh Handedness inventory, Type A/B behaviour pattern scale, General Health Questionnaire, and tests from NIMHANS Neuropsychological test battery. The results showed that neuropsychological performances of the MI patient group were significantly poor in the domains of mental speed and information processing; sustained attention; executive functions: category fluency, phonemic fluency, verbal working memory and response inhibition; verbal learning and memory; visual learning and memory; and visuo-spatial ability compared to the healthy normal matched group. Moreover, $52.5 \%$ of the MI patients were depressed. Type A behavior was significantly linked to myocardial infarction. The cognitive deficits and depression which are seen in the present study might have resulted from the disruption of neural networks that connect cortical and subcortical regions of the brain.
\end{abstract}

Index Terms-Myocardial infarction, type a behavior, depression.

\section{INTRODUCTION}

In cardiovascular disease, which is one of the leading causes of death in developing countries, the majority of deaths are due to myocardial infarction (MI). Myocardial infarction, commonly known as heart attack, occurs when the blood supply to parts of the heart is interrupted causing some heart cells to die. Myocardial infarction is considered to be a life threatening condition since it may result in an

Manuscript received February 20, 2013; revised May 22, 2013.

Sherin P. Antony is with the department of Psychology, Acharya Institute of Graduate Studies, Bangalore, Karnataka, India (e-mail: sherin.anil@yahoo.com).

M. I. Joseph is with the Department of Psychology, SreeSankaracharya University of Sanskrit, Kalady, Kerala. irreversible damage to the heart. It has estimated that in 2002, 12.6 percent of the deaths worldwide were due to myocardial infarction [1]. It is a major threat to the health of middle aged and elderly men and women. It also affects Indians at a younger age (in their 30 s and 40s) than is typical in other countries. The maincauses or risk factors of myocardial infarction are hypertension, diabetes mellitus and tobacco use. Psychosocial factors such as Type A behavior pattern or coronary prone behavior and depression have been reported to be associated with myocardial infarction.

Review of neuropsychological studies on MI patients show that MI patients have cognitive deficits in attention, rate of information processing and memory functions [2], impairment in word fluency, manual dexterity, verbal learning and psychomotor speed [3]. In addition, MI patients are seen to have depression [4]. Also it has been found that the incidence of myocardial infarction is twice as great among Type A individuals than among Type B individuals [5]. However later studies suggest that not all components of Type A behavior may be coronary prone and that some may even be protective.

Only few attempts have been made to find out the clinical and neuropsychological aspects of MI such as depression, Type A behavior pattern and cognitive functions. In view of the above, the present study was an attempt to characterize clinical and neuropsychological profiles of MI patients in the Indian context.

\section{METHOD}

One of the main objectives of the present study is to compare the neuropsychological performances of patients with myocardial infarction (MI) with that of a healthy normal group of matched subjects and to examine the presence of neuropsychological deficits in patients with MI before surgery and after surgery. Another important objective of the study is to compare these two groups on the prevalence of depression and Type A behavior pattern. The above objectives necessitate two sample groups: the main sample consisting of MI patients, and a comparison sample consisting of a matched group of healthy normal subjects.

Tests were administered in the MI patient group at presurgery. Both the groups were screened using Edinburgh Handedness Inventory. Additionally, the healthy normal group was screened using General Health Questionnaire- 12 for psychiatric symptoms. The patient group was administered a battery of neuropsychological tests to assess their neuropsychological functioning, Beck Depression Inventory to assess depression, and Type A behavior pattern scale to evaluate their behavior pattern. The matched group 
was administered the battery of neuropsychological tests and the Type A behavior pattern scale. Since the matched group was already screened for psychiatric symptoms using GHQ, the depression inventory was not administered.

The collected data were analyzed using appropriate statistical methods employing SPSS 15 version. The main statistical techniques employed included were Frequency and Percentage, Mean and standard deviation, Student's ' $t$ ' test, and Chi- square test.

\section{RESULTS}

\section{A. Clinical Characteristics and Risk Factors of Myocardial Infarction}

Hypertension alone is found to be present in in $7.5 \%$ of MI patients. Diabetes alone is found to be present in $25 \%$ of MI patients. Both hypertension and Diabetes was present in $40 \%$ of the patients. On Beck Depression Inventory, $55 \%$ of MI patients scored above the cutoff score which revealed that $55 \%$ of the patients were depressed before surgery and $52.5 \%$ of the patients were depressed after surgery. With respect to Type $\mathrm{A} / \mathrm{B} / \mathrm{AB}$ behavior, majority of $\mathrm{MI}$ patients are Type A (67.5\%) while Type A/B constituted $32.5 \%$ of MI patients. There were no patients with Type B behavior pattern in the patient sample.

\section{B. Neuropsychological Deficits in Mi Patient Group before Surgery when Compared to Healthy Normal Matched Group}

One of the main hypotheses of the study was about the pre-operative neuropsychological performance of the MI patient group compared to healthy normal matched group. Students 'test was carried out to see if the MI patient group differed significantly from the healthy normal matched group.

\begin{tabular}{|c|c|c|c|c|c|c|}
\hline \multirow[t]{2}{*}{ Domains } & \multirow[t]{2}{*}{ Tests } & \multicolumn{2}{|c|}{$\begin{array}{l}\text { MI patient group } \\
\text { presurgery }(\mathrm{N}=40\end{array}$} & \multicolumn{2}{|c|}{$\begin{array}{l}\text { Matched group } \\
(\mathrm{N}=\mathbf{4 0})\end{array}$} & \multirow[t]{2}{*}{ ' 't' value } \\
\hline & & $\mathbf{M}$ & SD & M & SD & \\
\hline $\begin{array}{l}\text { Mental } \\
\text { speed }\end{array}$ & DST & 291.8 & 87.16 & 221.20 & 69.85 & $3.99^{* * * *}$ \\
\hline $\begin{array}{l}\text { Sustained } \\
\text { Attention }\end{array}$ & DVT & 528.9 & 126.25 & 444.40 & 103.21 & $3.28 * *$ \\
\hline $\begin{array}{l}\text { Category } \\
\text { Fluency }\end{array}$ & A N T & 11.9 & 2.44 & 14.03 & 2.67 & $3.67 * * *$ \\
\hline $\begin{array}{l}\text { Phonemic } \\
\text { Fluency }\end{array}$ & COWA & 12.1 & 4.60 & 14.13 & 2.91 & $2.29^{*}$ \\
\hline $\begin{array}{l}\text { Verbal } \\
\text { working }\end{array}$ & V N B & 8.6 & .58 & 9.00 & .00 & $3.82 * * *$ \\
\hline Memory & V N B & 7.5 & .96 & 8.90 & .30 & 8.79 *** \\
\hline $\begin{array}{l}\text { Response } \\
\text { Inhibition }\end{array}$ & $\begin{array}{l}\text { Stroop } \\
\text { effect }\end{array}$ & 311.8 & 129.19 & 155.78 & 40.0 & $7.30^{* * *}$ \\
\hline \multirow{3}{*}{$\begin{array}{l}\text { Verbal } \\
\text { learning } \\
\text { Memory } \\
\text { Visual } \\
\text { planning\& } \\
\text { Construction }\end{array}$} & $\begin{array}{l}\text { AVLT } \\
\text {-Total }\end{array}$ & 48.5 & 7.61 & 61.05 & 5.9 & $8.21 * * *$ \\
\hline & $\begin{array}{l}\text { CFT } \\
\text { Copy }\end{array}$ & 35.8 & 1.10 & 36.00 & .00 & 1.00 \\
\hline & $\begin{array}{l}\text { CFT- } \\
\text { DR }\end{array}$ & 18.5 & 6.99 & 29.7 & 4.01 & $8.76^{* * *}$ \\
\hline
\end{tabular}

The results given in Table I veiled that there were significant differences between the patient group and the healthy normal matched group in most of the neuropsychological test performances. The matched group has performed significantly better than the MI patient group in the domains of mental speed, sustained attention, phonemic fluency, category fluency, verbal working memory, response inhibition, verbal memory, and visual memory

\section{Neuropsychological Performances and Depression before and after Bypass Graft Surgery (CABG)}

Another important hypothesis of the study was regarding the preoperative and postoperative performances in neuropsychological functions and depression in patients undergoing $\mathrm{CABG}$ surgery. Paired ' $\mathrm{t}$ ' test was used to compare the performances of the MI patients preoperatively and postoperatively.

\section{TABLE II: MEANS AND SDS OF THE SCORES OBTAINED By Mi PATIENT GROUP (PRE AND POST-SURGERY) IN NEUROPSYCHOLOGICAL} PERFormANCES AND DEPRESSION, AND THE CORRESPONDING ' $T$ ' VALUES

\begin{tabular}{|c|c|c|c|c|c|c|}
\hline \multirow{2}{*}{$\begin{array}{l}\text { Domains } \\
\begin{array}{l}\text { Mental } \\
\text { speed }\end{array}\end{array}$} & \multirow{2}{*}{$\begin{array}{l}\text { Tests } \\
\text { DST }\end{array}$} & \multicolumn{2}{|c|}{$\begin{array}{l}\text { Patient group } \\
\text { pre-surgery } \\
\text { M SD }\end{array}$} & \multicolumn{2}{|c|}{$\begin{array}{l}\text { Patient group } \\
\text { post-surgery }\end{array}$} & \multirow{2}{*}{$\begin{array}{l}\text { 't' value } \\
5.64 * * *\end{array}$} \\
\hline & & 291.80 & 87.16 & 313.68 & 100.08 & \\
\hline $\begin{array}{l}\text { Sustained } \\
\text { Attention }\end{array}$ & DVT & 528.92 & 126.25 & 577.03 & 131.81 & $4.15 * * *$ \\
\hline $\begin{array}{l}\text { Category } \\
\text { Fluency }\end{array}$ & $\mathrm{ANT}$ & 11.93 & 2.44 & 11.38 & 2.29 & $2.01^{*}$ \\
\hline $\begin{array}{l}\text { Phonemic } \\
\text { Fluency }\end{array}$ & COWA & 12.15 & 4.60 & 10.80 & 3.72 & $3.52 * * *$ \\
\hline $\begin{array}{l}\text { Verbal } \\
\text { working }\end{array}$ & V N B 1 & 8.65 & .58 & 8.43 & .81 & $2.68 * *$ \\
\hline Memory & V N B 2 & 7.50 & .96 & 6.88 & .96 & $4.27 * * *$ \\
\hline $\begin{array}{l}\text { Response } \\
\text { Inhibition }\end{array}$ & $\begin{array}{l}\text { Stroop } \\
\text { test }\end{array}$ & 311.80 & 129.19 & 319.20 & 132.22 & $5.73 * * *$ \\
\hline $\begin{array}{l}\text { Verbal } \\
\text { learning \& } \\
\text { Memory }\end{array}$ & $\begin{array}{l}\text { AVLT } \\
\text {-Total }\end{array}$ & 48.53 & 7.61 & 47.85 & 9.02 & .71 \\
\hline $\begin{array}{l}\text { Visual } \\
\text { planning \& } \\
\text { Constructio }\end{array}$ & $\begin{array}{l}\text { CFT - } \\
\text { Copy }\end{array}$ & 35.83 & 1.10 & 35.80 & 1.26 & 1.00 \\
\hline $\begin{array}{l}\text { Visual } \\
\text { learning \& } \\
\text { memory }\end{array}$ & $\begin{array}{l}\text { CFT- } \\
\text { IR }\end{array}$ & 20.25 & 6.67 & 25.68 & 44.27 & .78 \\
\hline \multirow[b]{2}{*}{ Depression } & $\begin{array}{l}\text { CFT- } \\
\text { DR }\end{array}$ & 18.55 & 6.99 & 17.30 & 7.26 & $2.56^{* *} *$ \\
\hline & BDI & 10.58 & 5.9 & 10.73 & 6.36 & 0.49 \\
\hline
\end{tabular}

It is seen from Table II that the patients performed significantly better pre-operatively than post-operatively in the domains of phonemic fluency, category fluency, verbal working memory, mental speed and visuomotor coordination, sustained attention, response inhibition, and verbal and visual memory-delayed recall. There are no significant differences between the preoperative and postoperative performances of the patients in the domains of verbal memory- immediate recall and recognition, visual 
planning and construction, and visual memory - immediate recall.

Table II also presents the scores of depression in the patients both pre-operatively and post-operatively. The result indicated that there was no significant difference between the pre- operative and post- operative mean scores in depression. Pre-operative and post-operative mean scores of depression in MI patient group were 10.58 and 10.73 respectively.

Fortunately there was no operative mortality or major neurological complication in the sample of 40 patients after bypass surgery.

\section{Comparison of the MI Patient Group and the Matched Group on Type a Behavior Pattern}

Type A persons are illustrated as people with a highly competitive desire for achievement and recognition, together with a tendency towards hostility and aggression and a sense of immense time urgency and impatience. It has been found that the incidence of myocardial infarction is twice as great among Type As' than among Type Bs'. The Type A pattern has both positive and negative aspects. While Type A behavior may increase proneness to heart related illness and death, it also gives them the drive to do particularly well in certain kinds of tasks. It is important to know the association of Type A behavior pattern with myocardial infarction and the pathological factors of Type A which leads to coronary problems.

Type A behavior pattern scale was administered to all the MI patients before surgery and to the normal matched group. Each subject yielded Type A score and Type B score separately and on the basis of the scores obtained, they were classified as Type A, Type B and Type AB. Both the patient and the matched groups were compared to see if there was any significant difference between the groups with respect to Type A, Type B, and Type AB behavior patterns using chi-square analysis. Also, both the groups were compared with respect to the factors of Type A and Type B that leads to coronary problems.

TABLE III: NUMBER OF SUBJECTS IN THE PATIENT AND THE MATCHED GROUPS WITH RESPECT TO TYPE A BEHAVIOR PATTERN AND THE

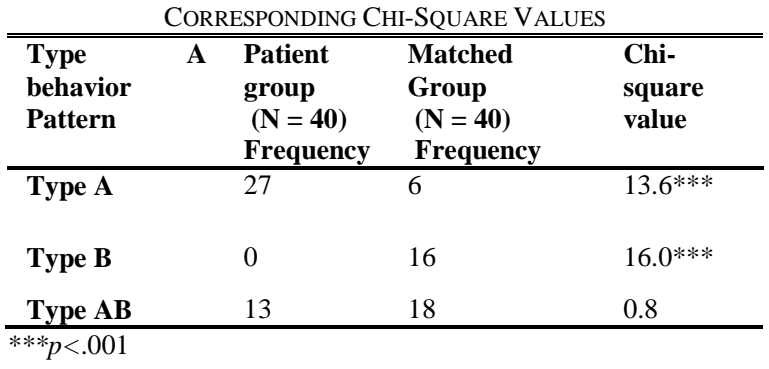

The results presented in Table III showed that there are significant differences between the patient group and the matched group with respect to the number of subjects with Type A, and Type B behavior pattern. The results showed that the number of subjects with Type $A$ and Type AB behavior pattern was higher among the patient group than among the matched while the number of subjects with Type $\mathrm{B}$ behavior pattern is 0 in patient group, there are 16 subjects in the matched group with Type B behavior pattern.

The above findings indicated that subjects with Type A behavior pattern are significantly predominant, in the MI patient group while subjects with Type B behavior pattern is totally absent in the group. Subjects with Type AB behavior pattern are present in both the patient and the matched groups.

\begin{tabular}{|c|c|c|c|c|c|}
\hline \multirow[t]{2}{*}{ Factors } & \multicolumn{2}{|c|}{$\begin{array}{c}\text { Patient group } \\
(\mathrm{N}=\mathbf{4 0}) \\
\mathrm{M}\end{array}$} & \multicolumn{2}{|c|}{$\begin{array}{l}\text { Matched } \\
\text { group } \\
\qquad(\mathrm{N}=40)\end{array}$} & \multirow[t]{2}{*}{ t value } \\
\hline & SD & & M & SD & \\
\hline Tenseness & 13.78 & 2.13 & 10.33 & 2.81 & $6.18 * * *$ \\
\hline Impatience & 8.73 & 1.69 & 7.35 & 1.46 & $3.89 * * *$ \\
\hline Restlessness & 10.10 & 2.28 & 8.20 & 2.27 & $3.73 * * *$ \\
\hline $\begin{array}{l}\text { Achievemen } \\
\text { t }\end{array}$ & 11.35 & 1.42 & 10.20 & 2.20 & $2.78 * *$ \\
\hline $\begin{array}{l}\text { Domineerin } \\
\text { g }\end{array}$ & 10.88 & 2.22 & 8.38 & 1.71 & $5.65 * * *$ \\
\hline Workaholic & 7.05 & 1.92 & 6.43 & 1.81 & 1.50 \\
\hline Total & 61.15 & 7.87 & 50.68 & 8.24 & $5.81 * * *$ \\
\hline
\end{tabular}

***p<.01;***p<.001

The results (Table IV) indicated that in the present study tenseness, impatience, restlessness, achievement and domineering factors of Type A may be related to health problems in the patient group compared to the matched group. This finding agrees with many previous findings. It has pointed out that impatience and restlessness are consistently related to health problems [6]. As ref [7] stated that below the superficial achievement striving, there may be an intense sense of inadequacy and perhaps low selfesteem which lead to negative self-evaluation and health problems. Moreover, Type A persons experience strong stress reactions and tenseness which lead to high risk of heart related illness and death.

\section{DISCUSSION}

In the present study, the neuropsychological profiles of the MI patients indicate impairments in the domains of mental speed and information processing; sustained attention; executive functions- phonemic fluency, category fluency, working memory and response inhibition; verbal learning and memory; and visual learning and memory.

Neuropsychological impairments in mental speed, attention and working memory deficits might interfere with task performance and task completion. Impairments in response inhibition could lead to behavioral problems in terms of impulsivity and disinhibition, which will interfere 
with goal driven behavior. Fluency deficits can hamper the patient's communication. Learning and memory deficits might lead to total dysfunctioning in their life and it may impede the patient's ability to engage in the rehabilitation effectively. The cognitive deficits which are seen in the present study might have resulted from the disruption of the neural circuits that sub-serve cognition and affect.

Symptoms of depression are commonly reported among patients with myocardial infarction. The results obtained in the present study also showed that there are significant differences between the MI patient group and the matched group with respect to the proportion of subjects with Type A, Type B and Type AB behavior pattern. It was also found that Type A behavior pattern is significantly more predominant in the MI patients than in the normal subjects whereas Type B behavior pattern is significantly less predominant in the MI patients compared to the normal subjects. This finding is corroborated by the findings of other studies on MI patients that have found association of Type A behavior pattern and myocardial infarction [8]-[10].

It has reported in ref [5] that not all of the components of Type A behavior may be coronary prone and that some may even be protective. The MI group in the present study had significantly higher scores than the matched normal group on the factors of Type A such as tenseness, impatience, restlessness, achievement, and domineering. Tenseness is the sense of time urgency. Restlessness means not feeling relaxed, while domineering is the sense of power over anything. Impatience is the inability to wait calmly, and achievement .orientation is the need to achieve something worthwhile whenever there is a possibility.

The results of the present study support the theory given in ref [11] which suggested that in situations where control over behavior is lacking, Type A persons exhibit relentless striving which leads to frustration and exhaustion despite the fact that the situation is challenging. In this situation, Type A people will feel more helplessness than Type $B_{s}$. Thus, Type $A_{s}$ will suffer from cycles of hyperresponsiveness and hypo-responsiveness, which are both associated with a pattern of physiological response which can be linked to the processes which may cause the development of coronary heart disease.

If Type $A_{s}$ are exposed to repeated failures, they tend to exhibit significant helplessness effects. It has been reported that factors of Type A like hard driving, aggression, competitiveness, job involvement, speed, impatience, hurried behavior, and anger were associated with the risk level of coronary heart diseases. The Type A component, engagement-involvement, acted as a protective factor. Thus, the present study provides an important link between specific factors of Type A behavior pattern and myocardial infarction.

The major limitation of this study was the small sample size and less number of subjects. Although more comprehensive statistical analyses like analysis of variance and repeated measures were planned, they could not be carried out since sufficient number of subjects was not available in the different cells for analysis. Post test of the normal matched group could not be made since many of the subjects in the matched group could not be traced. The present study could not make follow-up measures of the variables examined.

\section{ACKNOWLEDGMENT}

The Author acknowledges the cooperation of the patients who willingly participated in this study

\section{REFERENCES}

[1] World Health Organization, Integrated management of cardiovascular risk, Geneva: Switzerland, 2002.

[2] S. C. Knipp, N. Matatko, M. Schlamann, H. Wilhelm, M. Thielmann, M. Forsting, H. C Diener, and H. Jakob, "Small ischemic brain lesions after cardiac valve replacement detected by diffusionweighted magnetic resonance imaging: Relation to neurocognitive function," European Journal of Cardiothoracic Surgery, vol. 28, pp. 88-96, 2005

[3] G. Vingerhoets, G. V. Nooten, and C. Jannes, "Neuropsychological impairment in candidates for cardiac surgery," Journal of the International Neuropsychological Society, vol. 3, pp. 480-484, 1997.

[4] N. F. Smith and F. Lesperance, "Depression and other psychological risks following myocardial infarction," Archives of General Psychiatry, vol. 60, no. 6, pp. 627-636,1993

[5] K. J. Palmer, M. Pauline, M. T. Jones, and T. Christopher, "The relation of the Type A behavior pattern, factors of the structured interview, and anger to survival after myocardial infarction," Australian Journal of Psychology, vol. 44, no. 1, pp. 13-19,1992.

[6] V. Price, Type a Behavior Pattern: A Model for Research and Practice, New York: Academic press, 1982.

[7] J. T. Spence, R. L. Helmreich, and R. S. Pred, "Impatience versus achievement strivings in the Type A pattern: Differential effects on students' health and academic achievement," Journal of Applied Psychology, vol. 72, pp. 522-558, 1987.

[8] J. A. Blumenthal, R. Williams, Y, Kong, S. M. Schanberg, and L. W. Thompson, "Type a behavior and angiographically documented coronary disease," Circulation, vol. 58, pp. 634-639, 1978

[9] P. R. Falger, "Behavioral factors, life changes, and the development of vital exhaustion and depression in myocardial infarction patients," International Journal of Behavioral Development, vol. 6, no. 4, pp. 405-42, 1983.

[10] R. Ghulam, S. R. Gupta, B. Bandyopadhyaya, and S. N. Mishra, "Coronary prone behavior and coronary heart disease," Indian Journal of Psychiatry, vol. 32, no. 1, pp. 35-38, 1990.

[11] D. C. Glass, Behavior Patterns, Stress and Coronary Disease, Hillsdale, N. J.: Lawrence Erlbaum Associates, 1977.

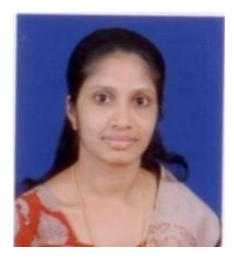

Sherin P. Antony is a native of Thrissur, Kerala in India was born on3 January 1981. She took her PhD (2011) in psychology from SreeSankar- acharya University of Sanskrit, M.Phil (2006) Clinical Psychology from National Institute of Mental Health and Neurosciences (NIMHANS) after her M.Sc (2004) and \& B Sc(2001) in Psychology from the University of Calicut.

She is presently working as an Assistant Professor and student's 4 counselor at Acharya Institute of Graduate Studies, Bangalore, India, affiliated to the University of Bangalore. Her published paper includes Neuropsychological Deficits in Myocardial infarction in Journal of NeuropsychologicalTrends. April 7. PP 37-50.(2010).

Dr. Sherin P Antony is also a registered Clinical Psychologist approved by Rehabilitation Council of India (RCI). 